\title{
IAMJ
}

INTERNATIONAL

AYURVEDIC

MEDICAL JOURNAL

ISSN: 2320-5091

Impact Factor: 6.719

\section{A CRITICAL UNDERSTANDING OF PCOS AND ITS EFFECTIVE AYURVEDIC MANAGEMENT- A CASE STUDY}

\section{Vaishnavi Vinayak Joshi}

3rd Year PG Scholar Panchakarma

Tilak Ayurved Mahavidyala Pune

Dr. Rajendra Huparikar. HOD Panchakarma, Tilak Ayurved Mahavidyala, Pune, Maharashtra, India

Corresponding Author: drjo1995@gmail.com

https://doi.org/10.46607/iamj3309052021

(Published Online: May 2021)

Open Access

(C) International Ayurvedic Medical Journal, India 2021

Article Received: 12/04/2021 - Peer Reviewed: 04/05/2021 - Accepted for Publication: 05/05/2021

(A) Check for updates

\section{ABSTRACT}

Polycystic ovarian syndrome is the most common endocrine disorder in India. It causes due to hormonal imbalance, there are enlarged ovaries with small cysts on the outer edge. Basically, cysts are formed due to thickening of tunica albugenia. In this syndrome there is a combination of excess of androgen and ovarian dysfunction. An etiology of syndrome remains largely unknown. It might be disorder with strong environmental influence, including diet, lifestyle, lack of exercise and heredity. While considering Ayurvedic perspectives, one should understand concept of Jathragni mandya as well as Dhatvagni mandya. It occurs due to defective Rutu, Kshetra, Ambu and Beeja. PCOS may occurs due to Santarpanjanya hetu or sometimes due to Apatarpanjanya hetu. Principle of treatment is based upon Hetu Sevana and either Stotorodhjanya samprapti or Dhatukshayajanya samprapti. According to Acharya kashyap it can be compared with Pushpaghni and Revati.

Keywords: PCOS, PCOD, Dhatvagnimandya, Pradar. 


\section{INTRODUCTION}

Polycystic ovarian syndrome is relative common endocrine disorder found in around $70 \%$ of women. It is the condition in which ovary fails to perform its normal function due to multiple cysts on the ovary. An estimated one in five $(20 \%)$. Indian women suffer from PCOS. PCOS was firstly described in 1935. However, there is general lack of awareness regarding the condition in India and it often remains undetected for years. Prevalence of polycystic ovarian syndrome in India adolescents ranging from $2-26 \%$ and age ranged from 18 to 45 years. It is also called as
'Stein Leventhal' syndrome. Symptoms may include irregular scanty menses, menorrhagia, oligomenorrhea, amenorrhoea, dysmenorrhoea, obesity, dark patches on skin, loss of hairs, unwanted hair growth, acne, lower abdominal pain.

\section{Understanding Concept of PCOS: -}

There are following types of PCOS-

1. Insulin resistance-most common type

2. Pill- induced PCOS - second most common type

3. Inflammatory PCOS

4. Hidden PCOS

\section{Difference between PCOD and PCOS}

\section{PCOD}

1. In this, ovaries produce androgen in minute quantities. Ovaries release lot of immature /partially mature eggs which eventually turns into cysts.

2. Common symptoms include weight gain, irregular menses, loss of hairs, infertility.

3. It is the condition developed by hormonal imbalance.

\section{PCOS}

It is the metabolic disorder that is more severe than PCOD. In this ovary produces higher quantity of androgen and leads to formation of more than 10 follicular cysts in ovary, this stops release of egg leading to anovulation.

Common symptoms include loss of hairs, weight gain, irregular menses.

It is the disorder of endocrine system and more severe than PCOD.

\section{CASE STUDY -}

Chief Complaints: - Irregular menses, weight gain around 8 to $10 \mathrm{~kg}$, dark patches on nape of neck, loss of hairs, acne, abdominal pain, growth of unwanted hairs. All symptoms were present since 8 months.

H/O Present Illness: - A female patient aged about 18 years, c/o irregular menses like scanty and delayed menses. She started symptoms like weight gain, abdominal pain, loss of hairs, growth of unwanted hairs, dark patches on nape of neck since 8 months. She took metformin for 3 months and stopped since 5 months.

\section{Etiology And Its Ayurvedic Parlance: -}

- spicy food, non-vegetarian food, junk food.

Acharya charak says in 30th chapter of chikitsa sthana, if female consumes Lavan, Amla, Guru, Katu, Vidhahi, Atisnighdha, Pishita ahara then it may lead to Pradar.

- excessive consumption of curd, milk products, slumber, excessive water consumption.

If a woman consumes Gramya, Udaka, Krushara, Paya, excessive Dadhi sevan (curd), Shukta,Mastu, Sura (alcohol), it may lead to Vataprakopa acquiring Apan Kshetra.

\section{Symptomatology and Ayurvedic Parlance: -}

There is not any specific description about PCOS in Ayurvedic texts.

Hence,

"Vikarnamkushalo n jivhiyat kadachan|

$N$ hi sarvavikaranam namtosti dhruva sthitihi \|"

(Ch. Su .18/44)

"Sa eva kupito dosha samuthanvisheshtaha 
Sthanantaragatashchaiva janaytyaamyan bahun \|

Tasmadvikarprakrutirdhishthanaantarani ch |

Samuthan visheshashcha budhva karma samacharet||"

(Ch. Su. 18/45,46)

\section{Samprapti :-}

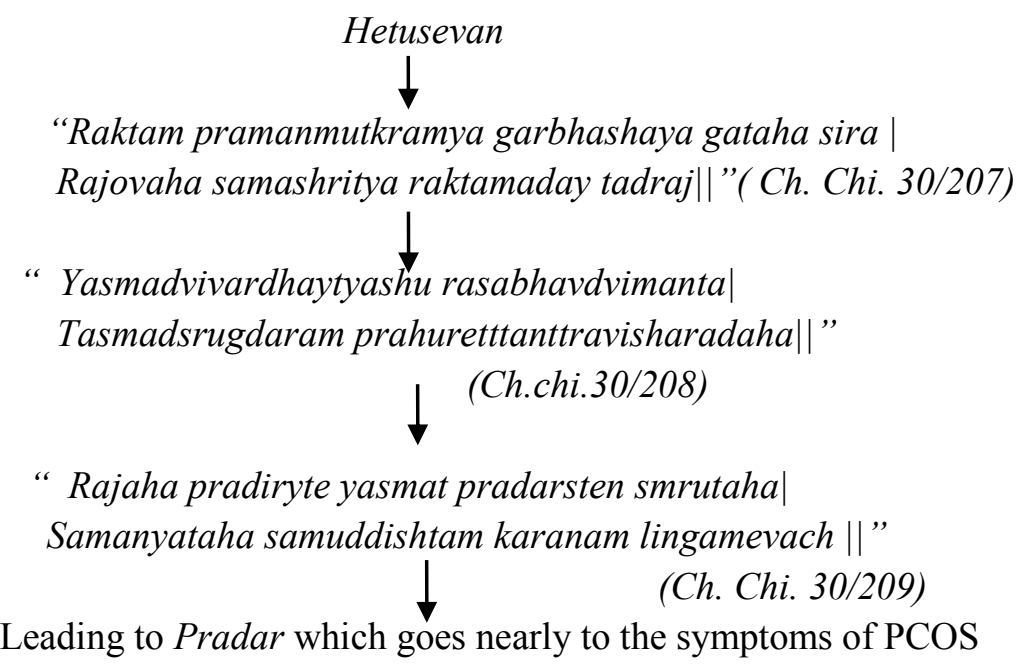

\section{Samprapti Ghatak:-}

Nidan-Kaphapitta Prakopak Hetusevn

Dosh - Tridosh

Dushya-Rasa, Rakta, Meda, Artava

Srotas - Rasa, Rakta, Meda, Artava

Strotodushti-Sanga, Atipravrutti

Agni-Angimandya

Doshagati - Koshtha

Rogmarga - Aabhyantara

Aam - Sam Kapha, Sam Pitta

Udbhava sthan - Garbhashay
Vyakta sthan - Garbhashay, Twak, Mamsa, Meda, Artava

Mode of Treatment: -

Principles of treatment are as follows.

1. To decrease Samata of body.

2. To treat Samkapha, Sampitta by Langhana, Pachana.

3. To treat Rasa dhatvagnimandya, Rakta, Meda dhatvagnimandya.

4. To use drugs having properties like Agneya, Ushna, Sukshma, Snighdha targeting Aartva Vaha Strotas.

\begin{tabular}{|c|c|c|}
\hline Name of drug & Dosage & Time \\
\hline 1. Kuberaksha vati & $250 \mathrm{mg}$ & 3 times a day \\
\hline 2. Shatapushpa churna & $2 \mathrm{gm}$ & 2times a day after, meal \\
\hline 3. Laghumalini vasant & $250 \mathrm{mg}$ & Rasayankaal \\
\hline 4. Syp.M2 tone & $20 \mathrm{ml}$ & 2 times after meal \\
\hline
\end{tabular}

Above treatment given to patient for 3 months.

\begin{tabular}{|c|l|l|}
\hline Name of drug & Pharmokinetics & Pharmodynamics \\
\hline 1. Kuberaksha vati & $\begin{array}{l}\text { Ushna, Snigha, Grahi, Deepan, Pachan, } \\
\text { Vatanuloman, Vibandha nashak }\end{array}$ & $\begin{array}{l}\text { Latakarnja-Laghu, Ruksha, Ushna, } \\
\text { Katuvipaki. } \\
\text { Rason-Ushna, Grahi, Deepan } \\
\text { Shunthi- Pachani, Aamvatghni, }\end{array}$ \\
\end{tabular}




\begin{tabular}{|c|c|c|}
\hline & & $\begin{array}{l}\text { Vrushya, Laghu, Kaphvatvibandhbhe- } \\
\text { dini, Agneygunbhuyishtha } \\
\text { Hingu- Ushna, Pachani, Katu- } \\
\text { shleshma anilhara. }\end{array}$ \\
\hline 2. Laghumalini vasant & $\begin{array}{l}\text { Ushna, Snighdha, Rasashudhhikara, } \\
\text { Navaneet (Butter)-Sheet Snighdhara- } \\
\text { sadhatuposhak }\end{array}$ & $\begin{array}{l}\text { Rasak-Balya, Rasayan, Kaphapit- } \\
\text { tanashak, Avarodhnashak }\end{array}$ \\
\hline 3. Shatapushpa & Madhura, Bruhan, Balya, Ushna & $\begin{array}{l}\text { Pushtivarna, } \\
\text { Rutupravartani, Yonshukra Vishodhi- } \\
\text { ni, Vataprashamani, Putraprada, } \\
\text { Veeryakari (ka.sh.) }\end{array}$ \\
\hline 4. Syp.M2 tone & $\begin{array}{l}\text { Madhura Ushna, Snighdha, Kashay, } \\
\text { Katurasatmak drvya }\end{array}$ & $\begin{array}{l}\text { Yonishukrapradoshvikar prasham, } \\
\text { Ayushya, Paushtik, Medya. (viz. } \\
\text { Ashwagandha, Kasis, Druharidra, } \\
\text { Gduchi, Sarviva, Shatavari) all drugs } \\
\text { having property of Rasa, Rak- } \\
\text { tadhatvagnivardhan. }\end{array}$ \\
\hline
\end{tabular}

\section{Result: -}

Before treatment (USG FINDINGS)

1. Uterus $2.2 * 7.0 * 3.6 \mathrm{~cm}$

2. Endometrial echo $7 \mathrm{~mm}$

3. Both ovaries appear polycystic

4. Right ovary volume $-4.6 \mathrm{cc}$, left ovary volume $-8.5 \mathrm{cc}$

5. Bilateral polycystic ovaries + delayed menses

\section{DISCUSSION}

PCOS is the disease in which there is endocrine impairment. Due to such condition there is need to give artificial hormones. While considering Ayurvedic perspective, Acharya Sushruta says Kshina Dosh should be increase by Bruhana, Sam dosha should maintain as it is, Kupita dosh should be treat by Prasham and Vrudd dosh should be eliminate. In Ayurveda balance of all doshas, dhatu and mala are important for health. In PCOS there is Dhatu Vaishamya present in Artava vaha Strotasa. There is need to treat the site of DoshaDushya Samurchana. In Ayurveda we do not treat only disease, but we treat individual as a whole. Hence this paper highlights that PCOS can be treated by understanding its Samprapti and Samprapti Vighatan can be done by correcting Jatharagnimandya, Rasa, Rakta, Meda, Artava Dhatvagnimandya. Also, it can be treated by using drugs which have properties like Aagneya, Ushna, Snigdha, Laghu and Vibandhanashak.
After treatment (USG FINDINGS)

1. Uterus $2.6 * 6.5 * 3.6 \mathrm{~cm}$

2. Endometrial echo $4 \mathrm{~mm}$

3. Both ovaries appear normal

4. Right ovary volume $-1.5 \mathrm{cc}$, left ovary volume- $2.4 \mathrm{cc}$

5. No significant abnormality is seen

\section{CONCLUSION}

Ayurvedic treatment which includes purification process, Agnideepan, Aampachan, regulate metabolism of affected Dhatu, Balavardhan and most important is Rejuvenation can be achieved in such conditions like PCOS. It is observed the following effects on this patient like increase in metabolic power (Agnideepan), Vatashaman, Kaphapitta Vibandha nashan, restoration of glandular activity and Ojovardhan. To sum up, the line of treatment was successful in this patient and eventually this patient has started regular menses without any health problems.

\section{REFERENCES}

1. Yadavaji Trikamaji Acharya, Charak Samhita Of Agnivesha Revised By Charak And Dhrudhbala With Ayurved Dipika Commentary By Chakrapani Datta, Choukhambha Surabharati Prakashan, Varanasi, 2016, Chikitsa Sthana, Chapter 30, Shloka 205 P 642. 
2. Yadavaji Trikamaji Acharya, Charak Samhita Of Agnivesha Revised By Charak And Dhrudhbala With Ayurved Dipika Commentary By Chakrapani Datta, Choukhambha Surabharati Prakashan, Varanasi, 2016, Chikitsa Sthana, Chapter 30, Shloka 206, P 642.

3. Yadavaji Trikamaji Acharya, Charak Samhita Of Agnivesha Revised By Charak And Dhrudhbala With Ayurved Dipika Commentary By Chakrapani Datta, Choukhambha Surabharati Prakashan, Varanasi, 2016, Sutra Sthana, Chapter 18, Shloka 44 To 46, P 108.

4. Yadavaji Trikamaji Acharya, Charak Samhita Of Agnivesha Revised By Charak And Dhrudhbala With Ayurved Dipika Commentary By Chakrapani Datta, Choukhambha Surabharati Prakashan, Varanasi, 2016, Chikitsa Sthana, Chapter 30, Shloka 207, P 643.

5. Yadavaji Trikamaji Acharya, Charak Samhita Of Agnivesha Revised By Charak And Dhrudhbala With
Ayurved Dipika Commentary By Chakrapani Datta, Choukhambha Surabharati Prakashan, Varanasi, 2016, Chikitsa Sthana, Chapter 30, Shloka 208, P 643.

6. Yadavaji Trikamaji Acharya, Charak Samhita Of Agnivesha Revised By Charak And Dhrudhbala With Ayurved Dipika Commentary By Chakrapani Datta, Choukhambha Surabharati Prakashan, Varanasi, 2016, Chikitsa Sthana, Chapter 30, Shloka 209, P 643.

\section{Source of Support: Nil \\ Conflict of Interest: None Declared}

How to cite this URL: Dr.Vaishnavi Vinayak Joshi: A Critical Understnading Of PCOS And Its Effective Ayurvedic Management- A Case Study. International Ayurvedic Medical Journal \{online\} 2021 \{cited May, 2021\} Available from: http://www.iamj.in/posts/images/upload/1136 1140.pdf 